\title{
Investigation of the presence of Aspergillus Flavus in mastitis milk with PCR
}

\author{
Kirkan Sukru $^{(1)}$, Parin Ugur ${ }^{(1) *}$, Aycen Ugur ${ }^{(2)}$, Yuksel Hafize Tugba ${ }^{(1)}$ \\ ${ }^{(1)}$ Adnan Menderes University, Faculty of Veterinary Medicine, Department of Microbiology, Aydin, \\ Turkey, 09016 \\ ${ }^{(2)}$ Adnan Menderes University, Institute of Health Sciences, Department of Microbiology, Aydin, \\ Turkey, 09016
}

Received: 22 November 2017

Accepted: 14 April 2018

Published online: 30 December 2019

\begin{abstract}
In this study, milk samples were taken in sterile $20 \mathrm{ml}$ containers from 90 cows with clinical mastitis in various enterprises around Aydın province between May-September 2017. The presence of Aspergillus flavus $\mathrm{M}_{1}$ toxin in milk samples was investigated by ELISA. Aflatoxin $\mathrm{M}_{1}$ ELISA results were compared with positive controls with $0 \mathrm{ppt}, 5 \mathrm{ppt}, 15 \mathrm{ppt}, 30 \mathrm{ppt}, 60$ ppt and 100 ppt. For the 88 samples examined; 5 ppt in 7 (8,0 \%), 15 ppt in $12(13,6 \%), 100$ ppt in $32(36,4 \%)$ and 0 ppt in $37(42,0 \%)$ aflatoxin $\mathrm{M}_{1}$ was detected. According to these results, $32(36,4 \%)$ AFM $_{1}$ positivity was detected in the European Union countries over the limit (50 ppt) accepted for raw milk. In our study, DNA obtained from 88 mastitis milk samples examined with Aflatoxin $\mathrm{M}_{1}$ ELISA kit was subjected to Aspergillus flavus species specific PCR process. As a result of PCR; Aflatoxin $\mathrm{M}_{1}$ at a level of 0 ppt in $7(36,8 \%), 5$ ppt in 1 (\% 5,2), $15 \mathrm{ppt}$ in $2(10,5 \%)$ and $100 \mathrm{ppt}$ in $9(47,5 \%)$ ELISA kit toxin presence was determined. As a result, 32 samples of $100 \mathrm{ppt} \mathrm{AFM}_{1}$ positivity were detected by ELISA and 9 samples 100 ppt positivity was detected by PCR in our study. The results of the ELISA test revealed that more positive results were formed due to cross-reactions, and the PCR method with FLA gene primers was more reliable for diagnosis.
\end{abstract}

Keywords: A. flavus, Aflatoxin M1, mastitis milk, ELISA, PCR

\section{Introduction}

"Mycotoxicosis" is the name of poisoning that occurs when mycotoxins are synthesized by fungi or are contaminated by food and feed by people and animals in various ways. As a result, carcinogenic, teratogenic, tremorogenic, hemorrhagic, dermal, hepatotoxic, nephrotoxic, neurotoxic effects occur and most importantly acute cases causing death are seen (Bakirc1 2014). The most important of these toxic effective metabolites are; aflatoxin, ochratoxin, patulin, zeralenon, trichothecene and fuminosins (Tunail 2000). In particular, Aspergillus species, especially mycotoxins, molds that provide the formation of spores, wind and various ways to reach far away areas can be transmitted to much different food and feed raw materials. In addition, temperature, humidity, nutrients,

${ }^{*}$ Corresponding author: Parin Ugur

e-mail: uparin@adu.edu.tr 
other mold species, geographical region, genetic factors and amounts of oxygen or carbon dioxide are important in terms of mold growth and mycotoxin synthesis (Girgin et al. 2001).

The most effective of the mycotoxins is the aflatoxin synthesized by some Aspergillus species. Aflatoxins with potential carcinogenic effect; direct milk and its products can be synthesized by developing molds, as well as indirectly consumed by molds containing animal food passes through the milk and milk products are processed in this is seen. The most effective aflatoxin species in milk is AFM1, the hydroxy metabolite of AFB1. Animals receiving AFB1 toxin in their body with contaminating feeds transmit biotransformation in the liver to the AFM1, which in turn feeds the mammary glands. The presence of AFM1 in milk and products is not only a problem for human health, but also very risky for infants and children (Oruç 2003).

In aflatoxin studies carried out in the world; the amount of aflatoxin may vary due to food type, climatic and regional factors. AFM1 level, the form of aflatoxin in the milk, is determined above the legal upper limits in our country and in the world regarding the presence of aflatoxin in milk (Rama et al 2015, 2016). In parallel with these studies, contamination sources causing contamination of aflatoxin in the milk, transmission route, abnormal state of contamination, etc. studies should be carried out to determine the precautions related to aflatoxin-causing fungi and environmental conditions.

Apart from the presence and economic effects of mastitis agents and aflatoxins which are not considered very much, they are now an important risk factor for human health and the economy of the countries. Studies on AFM1 being produced by A. flavus especially in milk should be continued and the findings and suggestions reached by evaluating the results of this study should be shared with related individuals and institutions. In this study, we tried to determine positive samples in terms of AFM1 presence by applying ELISA method to mastitis milk samples. Then mastitic milk samples were subjected to Aspergillus flavus type specific PCR and ELISA positive samples were compared. In conclusion, it is aimed to reveal the presence of AFM1 and the reliability of the applied method in mastitis milk samples.

\section{Material and methods}

\section{Collection of Specimen}

In this study, 90 samples of clinical mastitis in various hospitals in Aydin province and its surroundings were collected in sterile containers aseptically with $20 \mathrm{ml}$ of milk between May and September 2017. The samples were taken under the cold chain to the Laboratory of Microbiology Department of Adnan Menderes University Faculty of Veterinary Medicine and examined for the presence of A. flavus M1 toxin.

\section{ELISA}

The presence of A. flavus M1 toxin in milk samples was investigated using the Veratox for Aflatoxin M1 test kit (Neogen ${ }^{\circledR}$, Scotland) by ELISA technique. The analysis procedure was carried out in accordance with the manufacturer's instructions.

\section{DNA Extraction}

In our study, DNA extraction for PCR in pellets obtained by centrifugation of clinical mastitic milks was performed with Fermentas ${ }^{\circledR}$ DNA extraction kit.

\section{Positive Control}

Aspergillus flavus ATCC® (16883) was used as a positive control in the study. 


\section{PCR}

PCR amplification for a sample in PCR reactions for the detection of A. flavus was performed in a total volume of $25 \mu \mathrm{l}$, final concentration $2.5 \mu 1$ 10X PCR buffer, $1 \mu 150 \mathrm{mM}$ magnesium chloride ( $\mathrm{MgCl} 2), 0.25 \mu 1100 \mathrm{mM}$ dNTP, $1.25 \mu 1$ primer ( $20 \mu \mathrm{M}$ for each), $1 \mathrm{U}$ Taq DNA polymerase and $3 \mu 1$ (10 pg-10 ng) template DNA. The mixtures were transferred to PCR tubes and placed in a thermal cycler. PCR conditions was as follows: $95^{\circ} \mathrm{C} 5 \mathrm{~min}$ initial denaturation, $95^{\circ} \mathrm{C}$ for $30 \mathrm{sec}$ denaturation, $58^{\circ} \mathrm{C}$ for $30 \mathrm{sec}, 72^{\circ} \mathrm{C}$ for $45 \mathrm{sec}$ and $72^{\circ} \mathrm{C}$ for $5 \mathrm{sec}$, with a total of 26 cycles (Salgado et al. 2008).

\section{Results}

\section{ELISA results}

Aflatoxin M1 ELISA results were compared with 0 ppt, 5 ppt, 15 ppt, 30 ppt, 60 ppt and 100 ppt positive controls. Aflatoxin M1 ELISA results showed that 5 ppt in 7 (8.0\%), 15 ppt in 12 (13.6\%), $100 \mathrm{ppt}$ in 32 (36.4\%), 37 (42.0\%) in 32 Aflatoxin M1 was detected at 0 ppt levels (Table 13). 32 (36.4\%) of our samples were found to have AFM1 positivity over the limit (50 ppt) accepted for raw milk in the European Union countries.

Tab. 1. Aflatoxin $M_{1}$ ELISA results.

\begin{tabular}{|c|c|c|c|c|c|c|}
\hline \multirow{2}{*}{$\mathrm{n}$} & \multicolumn{6}{|c|}{ Aflatoxin Levels } \\
\cline { 2 - 7 } & $0 \mathrm{ppt}$ & $5 \mathrm{ppt}$ & $15 \mathrm{ppt}$ & $30 \mathrm{ppt}$ & $60 \mathrm{ppt}$ & $100 \mathrm{ppt}$ \\
\hline 88 & 37 & 7 & 12 & - & - & 32 \\
\hline
\end{tabular}

\section{PCR results}

In our study, DNA from 88 mastitic milk samples examined by Aflatoxin M1 ELISA kit were subjected to Aspergillus flavus type specific PCR. As a result of the PCR, positivity was determined in a range of $500 \mathrm{bp}$ band specific to 88 (19\% (21.6\%)'unda Aspergillus flavus.

When the findings of our study were examined, positive samples were detected in 19 samples by PCR, while AFM1 positivity of $100 \mathrm{ppt}$ was detected in 32 samples by ELISA. When PCR positive samples were evaluated according to ELISA results, 0 ppt in 7 (36.8\%), 5 ppt in $1(5,2 \%), 15$ ppt in 2 $(10,5 \%)$ and $100 \mathrm{ppt}$ in $9(47,5 \%)$ samples, Aflatoxin M1 toxin was detected. Only 9 (47.5\%) of our PCR positive samples were found to be AFM1 positive by ELISA.

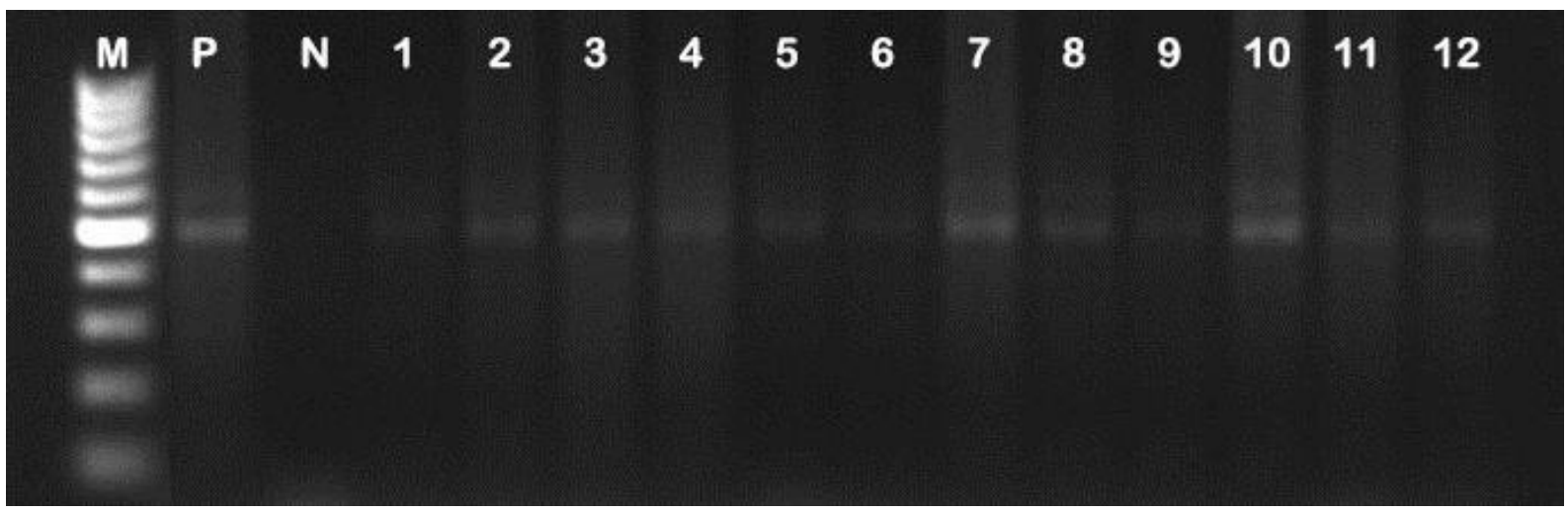

Fig. 1. Aspergillus flavus PCR result M: Marker, P: Aspergillus flavus ATCC® (16883) positive control, N: negative control, 1-12: Aspergillus flavus positive samples. 
S. Kirkan et al.

\section{Discussion}

Milk is the main source of nutrition for all people, especially infants and children. Considering this important point, the presence of AFM1 in milk and milk products is a global problem. The level of AFM1 in the plots can vary according to the geographical region, degree of development, and climatic conditions. Applications such as temperature, concentration, drying or product processing do not cause a significant change in the AFM1 concentration in the product. This situation requires comparing the AFM1 level in milk and products likely to be found in all foods that are likely to be aflatoxins in terms of individual and public health and as indicated in this study (Prandini et al. 2009, Picinin et al. 2013, Majid 2016).

Studies have been carried out to determine AFM1 detection and level in milk and products by using different techniques in the world and in Turkey. However, the ELISA method is widely used to determine the AFM1 concentration in milk (Tunail 2000, Majid 2016) because of the ease of use that is provided in products such as milk, too much reduction in pretreatment, short processing time, high sensitivity and simple application.

When the studies done by ELISA method and determination of the presence and level of AFM1 in milk and products are analyzed, highly variable findings are observed. In a study to identify AFM1 in 92 raw milk samples in Spain, 5 (5.4\%) of these samples were positive, but no quantities were found (Velasco et al. 2003). 113 raw milk samples were studied in Indonesia. AFM1 was found in 65 (57.5\%) samples and the mean value was determined as $0.009 \mu \mathrm{g} / \mathrm{kg}$ (Nuryono et al. 2009).

In a study conducted in Syria, AFM1 was investigated in 74 raw milk samples by ELISA method, $70(95 \%)$ specimens were positive, mean value was $0.14 \mu \mathrm{g} / \mathrm{kg}$ and $58.3 \%$ of the samples exceeded EU limits (Ghanem and Orfi 2009).

AFM1 was detected in 226 (94.2\%) samples using an ELISA method in Iran in 240 dairy samples, with an average of $0.013 \mu \mathrm{g} / \mathrm{kg}$, with $4.2 \%$ of all samples above the EU legal limit (Mohammadian et al. 2010).

A total of 895 milk samples, including 656 raw milk and 39 UHT milk in 2009 and 170 raw milk and 30 UHT milk collected in 6 different regions of Kosovo in 2009, were analyzed by ELISA method. Of 895 milk samples, 25 (2.8\%) samples were identified positive for AFM1. No contaminant sample exceeded EU limits of $50 \mathrm{ng} / \mathrm{l} .20$ (2.9\%) out of 685 samples in 2009 and 5 samples (2.5\%) out of 200 samples in 2010 were positive. Two of the UHT milk (2.6\%) were positive. While milk containing AFM1 was 5.2-26.6 ng/l in 2009, it was calculated as 6.3-9.81 ng/l in 2010. In UHT milk, 7.2-9.9 ng/l AFM1 was detected. In this case, the environmental factors on AFM1 have been clearly demonstrated (Rama et al. 2016).

In a study carried out in Erzurum, 72 different corn silages and 72 milk samples obtained from the animals fed with this feed, a study was conducted with ELISA for the transmission levels of AFB1 in the feed as super AFM1. In feed samples, AFB1 averaged around 361,12 \pm 94,76 ppt; AFM1 was detected at an average of $3.85 \pm 3.71 \mathrm{ppt}$ in milk samples. Super transmission of aflatoxin to feed was found to be $1.07 \% .66$ of the milk (91.67\%) are in AFM1 but below the acceptable limits according to the TGK. In the 69 feeds, AFB1 was recorded. With these results, it was seen that there was a positive correlation with the aflatoxin transmission from feed (Karakaya and Atasever 2010).

In the Marmara Region, 0.1-2 ppb (10-2000 ng/kg) AFM1 was detected in 101 cheese samples out of 110 provided from 30 military bases by ELISA method (Seyrek 2001).

Aflatoxin levels were investigated by ELISA in 300 cheese samples collected from differen military bases around Bursa province in Turkey. It is noted that $7.66 \%$ of these samples are in AFM1 and $1.66 \%$ of them are above the legal limits (Yaroğlu 2002).

In a study conducted in Van, a sample of 50 grain cheese and 25 samples of white cheese were investigated by ELISA method. The highest amount of $45.2 \%$ of the samples were found in white cheese 
S. Kirkan et al.

with $0.510 \mathrm{ppb}$ of AFM1 and $0.060 \mathrm{ppb}$ was measured with the lowest amount of grains were detected in cheese samples (Dağoğlu et al. 1995).

In a study conducted in Kars on AFM1 detection in ice cream; 50 samples of ice cream without packaging were analyzed by ELISA. The amount of AFM1 was found to be less than $0.005 \mu \mathrm{g} / \mathrm{kg}$ in 27 samples (54\%), more than $0.005-0.05 \mu \mathrm{g} / \mathrm{kg}$ in 6 samples (12\%) and more than $0.05 \mu \mathrm{g} / \mathrm{kg}$ in 17 samples (34\% these 17 were reported to be above EU and TGK limits (Sezer et al. 2013).

Products that are contaminating with aflatoxin can cause aflatoxicosis in humans and animals. In the face of this serious problem, it is important to identify all Aspergillus species, especially Aspergillus flavus and Aspergillus paraciticus species, from which aflatoxins originate. Despite the frequent use of ELISA and chromatographic methods in routine diagnostic assays, molecular diagnostics gain weight due to the disadvantage of biosynthesis and the disruption of the aflatoxin structure. PCR-based methods targeting DNA have been preferred for the rapid diagnosis of A. flavus and $A$. paraciticus with high sensitivity and specificity in the discovery of aflatoxigenic strains (Salgado et al. 2008), although different methods are used in different studies for this purpose.

Numerous molecular methods have been widely applied in the identification of Aspergillus species. DNA amplification and subsequent DNA sequencing is a powerful tool in taxonomy studies. The most commonly used DNA target regions to distinguish Aspergillus species are the internally encoded interspaces 1 and 2 (ITS1 and ITS2) in the rDNA complex and the variable regions at the 5 'end of the 28S rRNA gene and FLA1 FLA2 (Kumeda and Asao 1996, Ferrer et al. 2001, Hinrikson et al. 2005).

Single copy conserved genes can also be used as targets for taxonomic studies in the A. flavus group because the multiple copy segments from the rDNA complex do not vary. The universal $\beta$ tubulin, calmodulin and topoisomerase II genes have been used only in remotely related species to identify fungal species since variability is generally low (Kanbe et al. 2002). Genes involved in secondary metabolism are considered more variable in closely related species (Geiser et al. 2000). Several genes involved in aflatoxin biosynthesis have been identified, cloned, and examined. These have been identified from A. flavus including a regulatory gene locus and a few structural genes such as pKSA, nor-1, ver-1, uvm8 and omtA (Bhatnagar et al. 2006).

The specificity of the PCR assay specific for A. flavus was determined to be high relative to the positive PCR amplification obtained with a wide range of template concentrations (10 pg-10 ng) using DNA from pure cultures or contaminating sample. It has been reported that there is sensitivity in the agarose gel above $5.5 \mathrm{pg}$ for multiple copy sequences and above $87.5 \mathrm{pg}$ for single copy sequences (Jurado et al. 2006). A similar approach was applied by Sugita et al. (2004) for other pathogenic strains of A. flavus. Ribosomal DNA and its surrounding regions (including the ITS1 region) were used in the study, but $A$. flavus amplification susceptibility was determined to be low. Primers FLA1 / FLA2 were more efficiently detected to specifically amplify the A. flavus target sequence, and these primers are located in a more variable and specific portion of the ITS gene region (Somashekar et al. 2011).

In this study, 100 ppt AFM1 positivity was detected in 32 samples by ELISA and 19 samples were positive by PCR. When positive samples were evaluated by PCR using FLA1 and FLA2 primers according to ELISA results, 0 ppt in $7(36.8 \%), 5$ pt in $1(5,2 \%)$ inde and 15 ppt in $2(10,5 \%)$ and Aflatoxin M1 toxin level of 9 (47.5\%) unda 100 ppt. It is reported by Salgado et al. (2008) that FLA1 / FLA2 primers used in A. flavus identification are more specific in amplifying the target sequence and do not cross-react. In addition, A. flavus was detected using FLA1 / FLA2 primers in samples with ELISA values below the specified standards. More positive results with the ELISA test indicate that these results may be due to cross-reactions. For this reason, the presence of AFM1 was confirmed in 9 (10.2\%) samples, both PCR positive and $100 \mathrm{ppt}$ in the ELISA test. A. flavus PCR positive 10 (11.3\%) samples considered that the milk specimen should be controlled in the direction of AFM1. 
S. Kirkan et al.

\section{Conclusion}

Mycotoxins produced by molds are an important natural pollutant causing negative effects on human health by contaminating the nutrients at every stage from field to table. Storing or transporting food in unsuitable conditions, without adequate drying, is a major cause of mycotoxin contamination, where the humidity is high. The AFM1 found in milk contains the metabolites of lactating animals fed with feeds contaminating with AFB1, either as a result or as a result of aflatoxin production and subsequent transmission of aflatoxin-expressing molds during transportation, processing and storage. Milk and dairy products are a risky food group in terms of AFM1 residues. Aflatoxins are one of the major problems that threaten public health, as milk and dairy products are consumed in large quantities in the nutrient pattern of young children, one of the sensitive groups in society. For this reason, it is necessary to evaluate the exposure of AFM1 correctly and take the necessary precautions. Assessment of exposure to aflatoxin M1; the frequency of food consumption and food consumption are not properly taken, and aflatoxins are not homogeneously found in milk. Since AFM1, which is found in food can not be totally destroyed; it is advised by experts to take down AFM1 to the lowest possible levels. At the same time, diversity in nutrients, one of the healthy nutritional recommendations, may limit the intake of AFM1 with nutrients. In addition, for the reduction of AFM1 contamination; the adoption of good farming practices and the official control and enforcement mechanisms for it must be maintained in a healthy and effective manner at every stage from milk production to consumption. Since aflatoxin and A. flavus identification may result in false positive results due to cross-reactivity in ELISA testing, it is recommended that PCR-based diagnostic methods be used and AFM1 levels should be measured at regular intervals with repeated ELISA studies.

\section{Acknowledgements}

This work was supported by Adnan Menderes University Scientific Research Project Committee (Project code: VTF-17011).

\section{References}

Bakırc1 I (2001) A study on the occurence of aflatoxin M1 in milk and milk products produced in Van province of Turkey. Food Control 12:47-51.

Bhatnagar D, Cary JW, Erlich K, Yu J, Cleveland TE (2006) Aflatoxins. Mycopathologia 162:155.

Dağoğlu G, Keleş O, Yıldırım M (1995) Peynirlerde Aflatoksin Düzeylerinin Elisa Testi le Araştırılması. İstanbul Üniversitesi Veteriner Fakültesi Dergisi 21(2):313-317.

Ferrer C, Colom F, Frasés S, Mulet E, Abad JL, Alió JL (2001) Detection and identification of fungal pathogens by PCR and by ITS2 and 5.8S ribosomal DNA typing in ocular infections. Journal of Clinical Microbiology 39:2873.

Geiser DM, Harbinski FM, Taylor JW (2000) Integration of Modern Taxonomic Methods for Penicillium and Aspergillus Classification. Hardwood Academic Publishers, U.K, 381.

Ghanem I, Orfi M (2009) Aflatoxin M1 in raw, pasteurized and powdered milk available in the Syrian market. Food Control 20:603-605.

Girgin G, Başaran N, Şahin G (2001) Dünyada ve Türkiye'de İnsan Sağlığını Tehdit Eden Mikotoksinler. Türk Hijyen ve Deneysel Biyoloji Dergisi 58(3):97-118.

Hinrikson HP, Hurst SF, Lott TJ, Warnock DW, Morrison CJ (2005) Assessment of ribosomal largesubunit D1-D2, internal transcribed spacer 1, and internal transcribed spacer 2 regions as targets for molecular identification of medically important Aspergillus species. Journal of Medical Microbiology 43:2092.

Jurado M, Vázquez C, Marín S, Sanchis V, González-Jaén MT (2006) PCR-based strategy to detect contamination with mycotoxigenic Fusarium species in maize. Systematic and Applied Microbiology 29:681-689. 
S. Kirkan et al.

Karakaya Y, Atasever M (2010) Mısır Silajında Aflatoksin B1 Varlığının ve Süte Geçme Durumunun Araştırılması. Kafkas Üniversitesi Veteriner Fakültesi Dergisi 16:123-S127.

Kumeda Y, Asao T (1996) Single-strand conformation polymorphism analysis of PCR-amplified ribosomal DNA internal transcribed spacers to differentiate species of Aspergillus section Flavi. Applied and Environmental Microbiology 62:2947.

Majid H (2016) A survey of aflatoxin M1 in cow milk in Southern Iran. Razi Vaccine and Serum Research Institute, Shiraz Branch, Agricultural Research, Education and Extension Organization (AREEO), Shiraz, Iran.

Mohammadian B, Khezri M, Ghasemipour N, Mafakheri S, Langroudi P (2010) Aflatoxin M1 contamination of raw and pasteurized milk produced in Sanandaj, Iran. Archives of Razi Institute, 65:99-104.

Nuryono N, Agus A, Wedhastri S, Maryudani YB, Sigit Setyabudi FMC, Böhm J (2009) A limited survey of aflatoxin M1 in milk from Indonesia by ELISA. Food Control 20:721-724.

Oruç HH (2003) Süt ve Süt Ürünlerinde Aflatoksin M1 (AFM1) ve Türkiye'deki Durumu. Uludağ Üniversitesi Veteriner Fakültesi Dergisi 22:121-125.

Picinin LCA, Cerqueira MMOP, Vargas EA, Lana AMQ, Toaldo IM, Bordignon-Luiz MT (2013) Influence of climate conditions on aflatoxin M1 contamination in raw milk from Minas Gerais State, Brazil. Food Control 31:419-424.

Prandini A, Tansini G, Sigolo S, Filippi L, Laporta M, Piva G (2009) On the occurrence of aflatoxin M1 in milk and dairy products. Food Chemical Toxicology 47:984-991.

Rama A, Latifi F, Bajraktari D, Ramadani N (2015) Assessment of aflatokxin M1 levels in pasteurized and UHT milk consumde in Prishtina, Kosova. Food Control 57:351- 354.

Rama A, Montesissa C, Lucatello L, Galina G, Benetti C, Bajraktari D (2016) A study on the occurrence of aflatoxin M1 in milk consumed in Kosovo during 2009-2010. Food Control 62:52-55.

Salgado AG, Jaen TG, Vazquez C, Patino B (2008) Highly sensitive PCR-based detection method specific to Aspergillus flavus in wheat flour. Food Additives and Contaminants 25(6):758-764.

Seyrek K (2001) Türk Silahlı Kuvvetleri'ne Balı Birliklerde Tüketilen Beyaz Peynirlerdeki Aflatoksin M1 Seviyesinin ELISA (Enzyme-Linked immunosorbent Assay) Metodu ile Saptanması. Veteriner Hekimleri Derneği Dergisi 55-57.

Sezer Ç, Aksoy A, Vatansever L, Bilge N (2014) Kars İlinde Satışa Sunulan Dondurmalarda Aflatoksin M1 Varlığının Belirlenmesi. İstanbul Üniversitesi Veteriner Fakültesi Dergisi 40(1):90-94.

Somashekar D, Rati ER. Chandrashekar A (2011) PCR-restriction fragment length analysis of aflR gene for differentiation and detection of Aspergillus flavus and Aspergillus parasiticus in maize. International Journal of Food Microbiology, 93:101- 107.

Sugita C, Makimura K, Uchida K, Yamaguchi H, Nagai A (2004) PCR identification system for the genus Aspergillus and three major pathogenic species: Aspergillus fumigatus, Aspergillus flavus and Aspergillus niger. Medical Mycology 42:433-437.

Tunail N (2000) Funguslar ve Mikotoksinler. Medisan Yayınevi, Ankara, 4-34.

Velasco MLR, Delso MMC, Escudero DO (2003) ELISA and HPLC determination of the occurrence of aflatoxin M1 in raw cow's milk. Food Additives and Contaminants 20:276-280.

Yaroğlu T (2002) Türk Silahlı Kuvvetleri'ne Bağlı Birliklerde Tüketime Sunulan Peynirlerde Aflatoksin M1 Düzeylerinin Araştırılması. Uludağ Üniversitesi Sağlık Bilimleri Enstitüsü, Bursa. 